\title{
Enhancing Local Designers Skill in Rattan Furniture Industries in Cirebon through Comprehensive-Design Approach Regarding Buyers' Dependencies Prevention
}

\author{
Andar Bagus Sriwarno \& Imam Damar Djati \\ Research Group of Human and Industrial Product, Industrial Design Section, \\ Bandung Institute of Technology
}

\begin{abstract}
Between the 1970s and the 1990s, the Indonesian economy has been transforming from an agriculture-based to an industry-based economy. According to this condition, Cirebon growth rapidly to export rattan goods even this city has no resources in rattan. The lack of design quality, export regulation and global economic crisis become the main factor to affect the decrease of company's income at recent. Despite the crisis, government is now trying to recover by inviting design expert to improve design skills and capacity building of entrepreneurs in particular small-medium scale enterprises. This study aims to define why Cirebon still lags behind in industrial competitiveness regarding rattan furniture design. The intervention program of design is conducted to seek out the craftsman's ability and determined the kind of design competitiveness advantages according their nature of business.
\end{abstract}

Keywords: capacity building; competitiveness; design intervention.

\section{$1 \quad$ Introduction}

Rattan certainly is an exotic material for those living in non-tropical countries as it mostly grows in tropical regions, particularly Southeast Asia. Rattan furniture (Figure 1) is one of the province's top creative businesses that cause Cirebon as home of 80 percent of the country's total rattan enterprises. Indonesia is one of the biggest rattan producers in the world with a production capacity of 250,000 to 400,000 tons per year. Rattan industries in Cirebon are growth naturally without a proper master plan supported by a local government [1]. The lack of future orientation affects to the position that low in bargain position. This results in the low ability of a strong business management that can strengthen the position of the buyer. The appearance of business mechanism actually comes from the desire of the business stake holders on how to earn profit from the production quantity based on the specification of the buyer and ignores to improve the quality of production through new designs [2]. This cradled condition results the continuous order conditions for several years and the company gradually lost the ability in the development of design due to routine business that occurred repeatedly [3]. The change in national economic and political situation recently turn the business began to shock, where many 
employers are experiencing a business slowdown or even a bankruptcy. This shifted condition run increasingly and put the company into the second chain of business which results in the loss of competitiveness due to very low market bargaining [4].

It has been reported that this city is suffering a decline in rattan exports year by year significantly [2,5]. As reported by Santosa [4], the decline has been identified to issues that Ministry of Trade had introduced a regulation banning the export of the commodity in 2005. This current condition impacts to the lack of guarantee that Cirebon will have enough feedstock of raw rattan when quotas are imposed. In the other hands, where the access to information about design rights is not readily available to use, it is not possible to research beforehand whether the products ordered by the buyers infringe on existing design rights. Indonesia currently has design-protection laws on the books, but in places like Cirebon where businesses engaged in the same industry are concentrated in one locale, imitation goods often hit the market before there has been time for the original design to be registered. This is an indication of just how weak producers are when they are at the beck and call of buyers. It has to be emphasized that developing a legal environment that includes laws to prevent unfair competition and capacity building to rise design skills are vital to the intervention of design program. According to the above problems, in this study, rat-tan furniture enterprises in Cirebon were chosen as the destination for the development of creative industries study. In this research, a comprehensive skills improvement method is applied the to small-medium scale entrepreneurs prior to post government regulation effect.

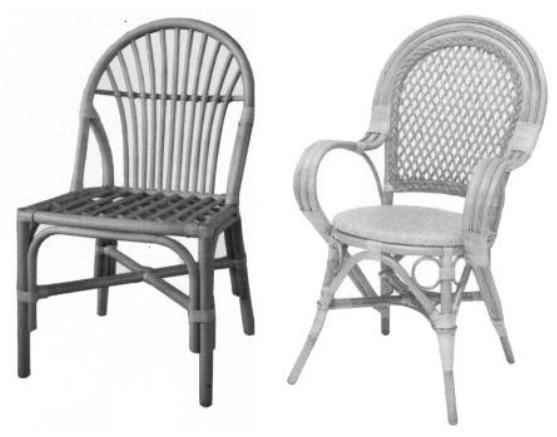

Figure 1 Typical design of rattan furniture in Cirebon.

\section{$2 \quad$ Methodology}

The numbers of participants were 40 local designers that selected from about 60 candidates. They were recruited under the requirement of certain ability of design including sketching, making technical drawing, and understanding to 
production line, and market analysis. The term of activity is named intervention design program and held periodically during August 2008 until June 2009 which comprises in two phases of activity. First activity is screening phase which to select participants as eligible person who will be observed and allow them to report the feed back of working activity in the factory. Second activity is an action program which is conducted based on the baseline data from screening phase. The venue of the program was in the Technical Support Center owned by Ministry of Trade and Industry in Cirebon.

\section{$3 \quad$ Results}

\subsection{Screening Phase (Participant's Subjective Data)}

Participants are requested to fill the form of questionnaire that investigating their company condition. The purpose of screening step is to asses the current situation concerning related design development that may lead to define existing problems. Figure 2 showed that companies have experience in design development since (d) a year ago (42\%), (c) five and (d) ten year ago (24\%), and (a) ten years ago (10\%). According to this data, most of companies have started to improve the design by themselves about a year ago (around 20072008). As predicted, method of design development regarding buyers specification are (b) modification from exist-ing products (65\%), (c) new product development (19\%), and (a) imitating successful design in the market $(8 \%)$.

The lack of design skills affect to the ability of modifying buyer's specification (Figure 3). In order to determine design specification, the owner of company has an almost dominant role (47\%) to decide an appropriate design for buyers (a), remains showed that marketing section (d) has $23 \%$ of decision maker whilst designer (c) contributes to propose design only in $17 \%$ to buyers (Figure 4). It is common to find that in-house designer often works not only for de-sign but also responsible to control the product quality (b) about $61 \%$, or material purchasing (a) about $24 \%$, or communicating with buyers (a) about $24 \%$, and marketing to delivery (d) about 5\% (Figure 5).

It was assumed that participants were not graduated from the school of design or related formal education. As shown in Figure 6, most of participants were not graduated from formal design school but they learned about design from various sources. They are able to draw and built the sense of art by them self (a) to improve their design skills about $67 \%, 21 \%$ of them were assisted by company's owner to under-stand the customer's life style, and only $9 \%$ is reported to attend the informal design training. Due to the lack of design skills, in order to meet the buyer's demand which come with none of design specification, $56 \%$ of participant response to create the design by modifying the 
existing design(c). $23 \%$ was re-ported to create a new design (b) even though the design often to be rejected by buyer. $19 \%$ was shown to copy or duplicate an existing design (a) and the remains data was informed that participants were not able to create buyer's specification (d) about 2\% (Figure 7).

It is common in Cirebon when company is found to invent a new design, other companies are motivated to conduct the similar way of development $(\mathrm{a} / 82 \%)$ as shown in Figure 8. 9\% is shown that local designers try to find any information about the method of design development (b) whilst $3 \%$ is re-ported to wait the market responses of the new product before copying (d). The lack of design skills regarding substitute material was confirm to the fol-owing data in Figure 9 which $64 \%$ of participants were not familiar to the methods of design development due to material combination approach (a) while $30 \%$ was reported to have enough capability with the method of material substitute such as abaca, banana fiber, and eceng gondok (water hyacinth species) (30\%). Only 6\% of companies reported to experience in combining natural material in the rattan furniture design (c). In the development of design skills (Figure 10), participants realize that the ability of decoding market trend is needed (c/49\%) whilst the lack of sketching also had to be taken into account ( $\mathrm{a} / 36 \%)$. Prior to pass the quality control, the ability to produce understandable drawing is also need to improve (b/18\%).

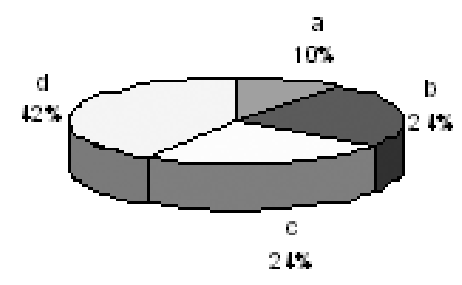

Figure 2 The period of design development experience in the company.

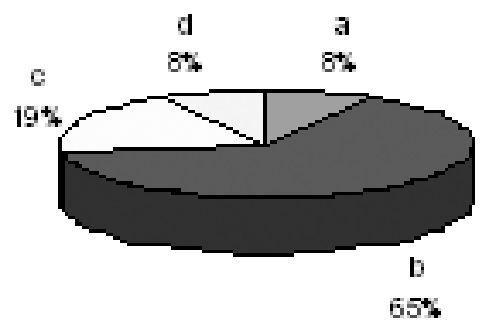

Figure 3 Method of design development. 


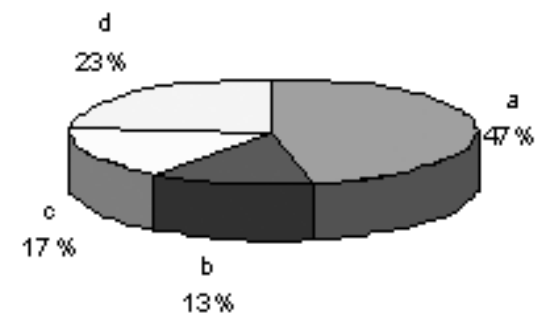

Figure 4 Determination of design judgment in the company.

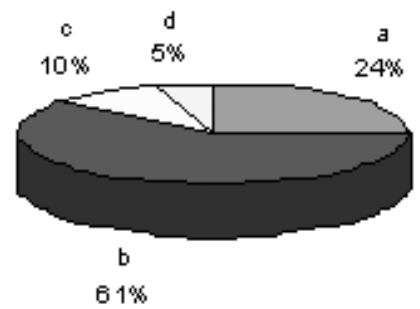

Figure 5 Overlapped-job handled by in-house designer.

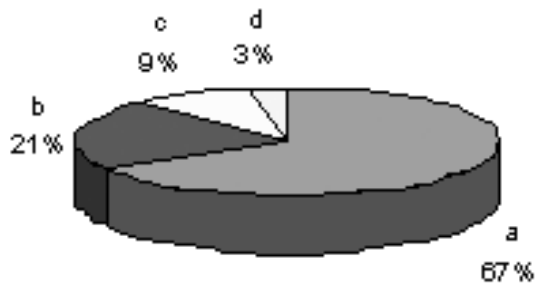

Figure 6 Self improvement about design skills.

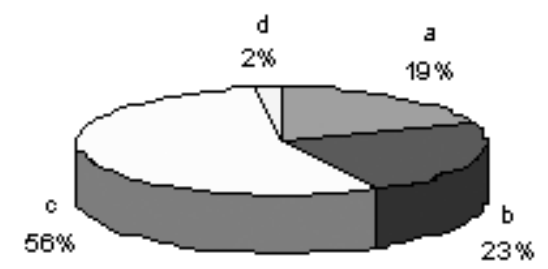

Figure 7 The way to determine buyer's design specification. 


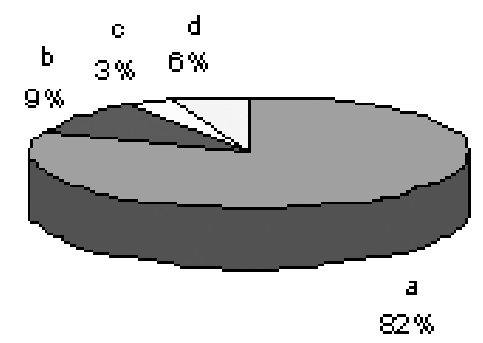

Figure 8 Method to launch a "new" design.

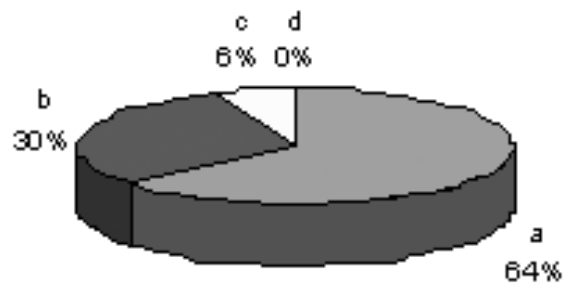

Figure 9 The distribution of knowledge proportion regarding substitute material.

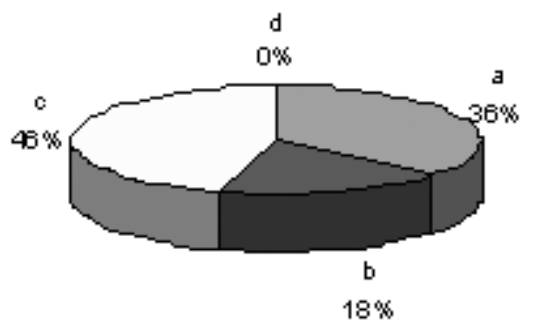

Figure 10 The need of specific ability of design.

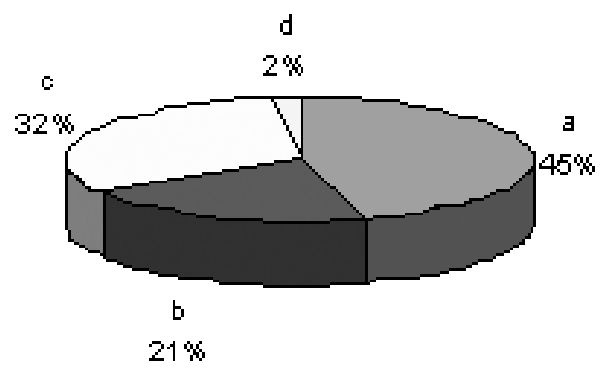

Figure 11 Expectation after participating intervention program. 
Interestingly, as shown in Figure 11, participants are motivated to develop their own design skills by building new enterprise instead as company's in-house designer $(\mathrm{a} / 45 \%)$ after attending intervention program. 32\% participants don't really care about whom they are belonging to but they pay attention to have a good sense to read the market trend and decode it into design (c/32\%).

Rests of participants are still consistent to stay in the companies by sharing their knowledge from the program (b/21\%).

\subsection{Action Phase}

\subsubsection{Introduction of Design (Basic Knowledge/Refreshment) and Memory Recalling}

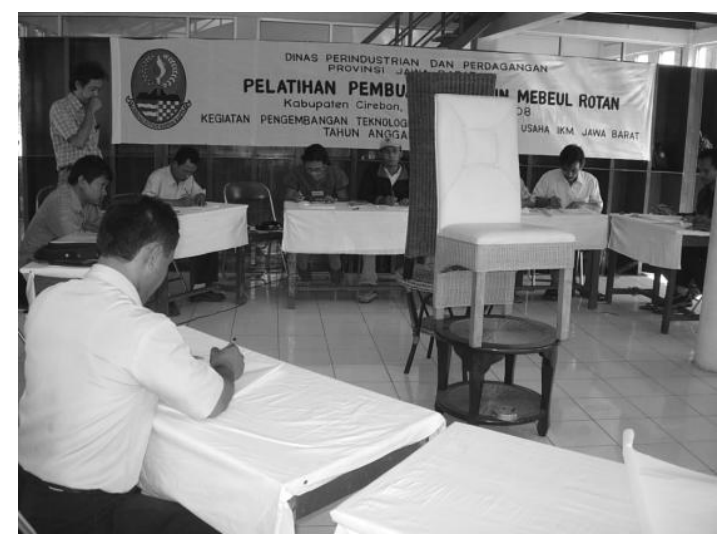

Figure 12 Reverse drawing and memory recalling.

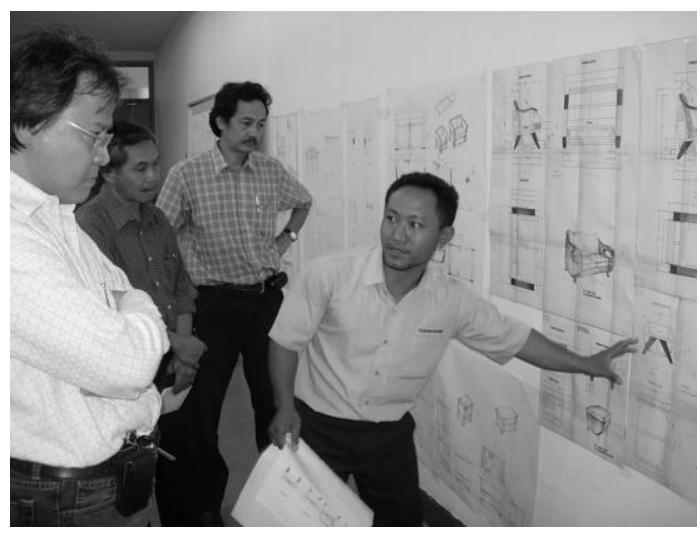

Figure 13 Design critics and feedback.

The material of action phase is including basic design, standardizationregulation, and design management. In this activity, participants are asked to 
define and map their related problems regarding design development. In accordance of drawing ability screening, participants are asked to draw the chosen furniture as like as possible. The next step was to re-drawing previous design without existing model in front of them (Figure 12).

\subsubsection{Consumer Behavior Study, Describing Consumer's Trend and Decoding Trend into Design}

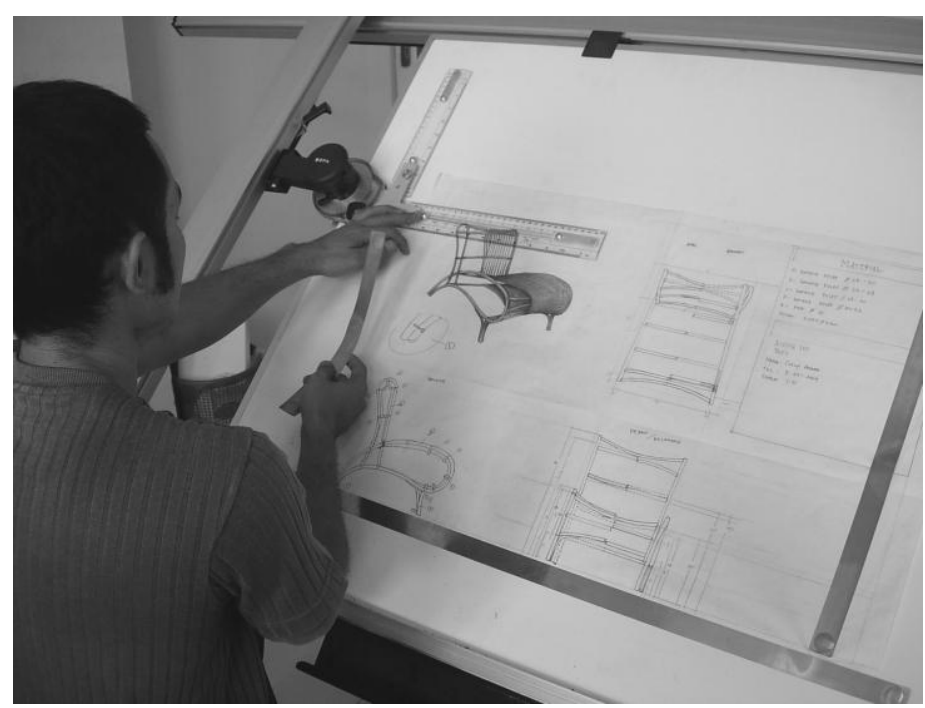

Figure 14 Sketching and generating idea of design.

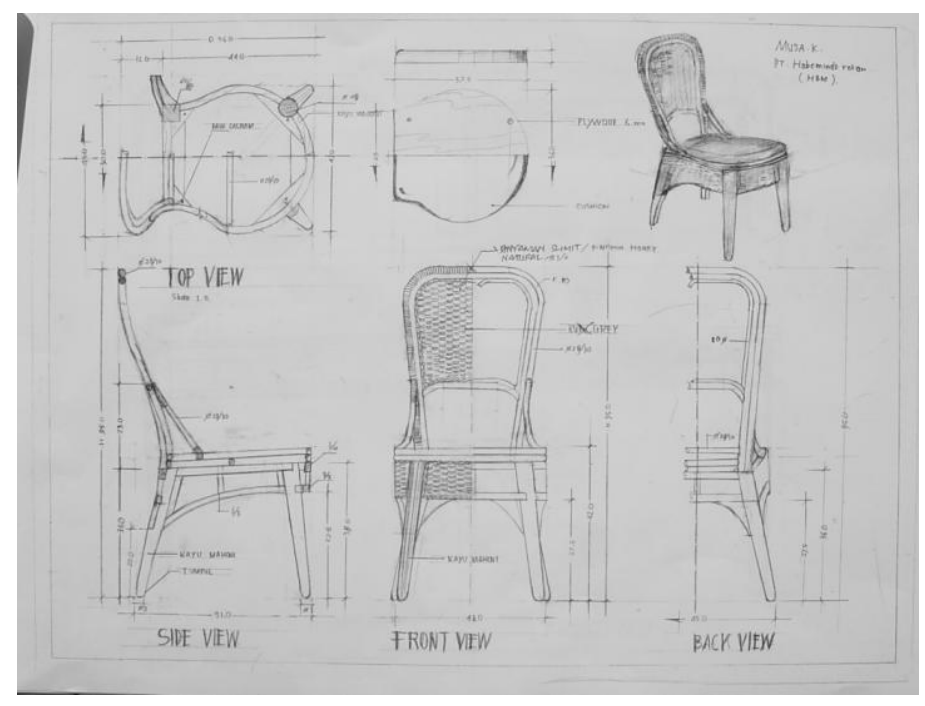

Figure 15 Updated technical drawing. 
According to the data in first phase, the lack of creativity in decoding the market's need is one of the problems to realize design sketch. In this activity, participants are motivated through visual stimulation which allows participants to break down the point of trend code. These codes (determined in adjective group of words) have to be transformed into the sketches (Figure 14) and technical drawing (Figure 15). Due to customers look for furniture that suits to their life style, sketches should like fashion that constantly easy to changes. It can be said that meeting consumers' tastes is vital in staying ahead of the market competition.

\subsubsection{Design Novelty (Intellectual Property Right/IPR Approach)}

Under the intellectual property rights system, design development based on IPR was introduced therefore participants understand about the importance of design registration. Applicants who are in the process of registering receive what is known as preliminary protection so that they can continue to run their businesses without having to wait for the issuance of their certificates. This was contrary to what was believed by many entrepreneurs that design can not be launched during evaluation process done by government which need over than 6 month [1]. The novelty of design which introduced in this activity was judged according to three method of judgments: searching an existing design from catalog, searching from www (online catalog and IPR database), and judgment from design expert (Head of Indonesian Furniture and Craft Association) as shown in Figure 13.

\subsubsection{Substitute Material Approach and Design Refinement}

The image of eceng gondok handicrafts and furniture is also on the rise on the overseas markets thanks to the massive back-to-nature campaign worldwide. Unlike rattan or wood or other natural materials, eceng gondok was introduced as a slightly thicker and much easier material to shape in forming and designing an item. The furniture also gives a more natural impression.

\subsubsection{Prototyping and Design Promotion for Exhibition}

The goal of all activities in design intervention is making prototypes (Figure 16) and preparing material for exhibition such as catalog (Figure 17). 


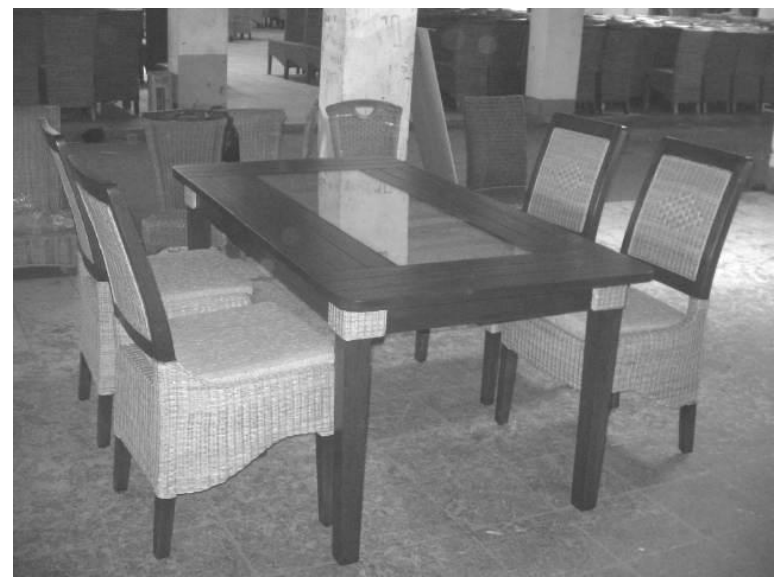

Figure 16 Prototyping.

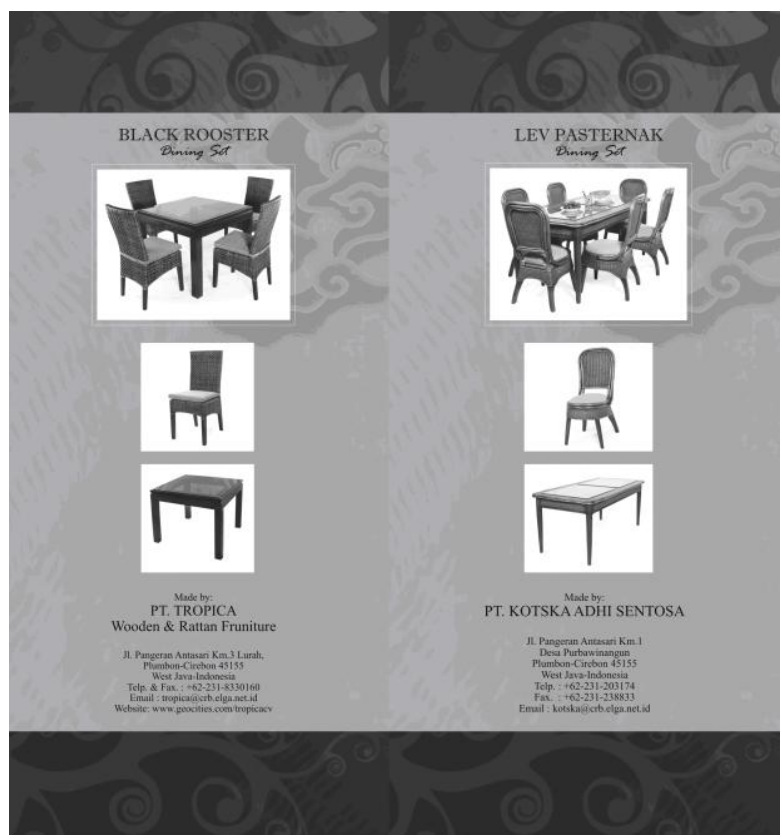

Figure 17 Design catalog for exhibition.

\section{$4 \quad$ Discussion and Conclusions}

The government regulation of raw materials export No. 12 in 2005 is just only a trigger to open the real problems in rattan business. The dependencies to buyer's specification let larger companies run their business into tailor made relationship and split the component to sub-producers. The lack of design 
awareness leads companies to imitate or copy the existing design which shows high demand in the market. Regarding design infringement, government doesn't seriously strictly enforce intellectual property rights, help the industry to diversify away from conventional raw materials and improve the laws, particularly on import and export procedures. The poor enforcement of intellectual property rights, particularly the protection of industrial designs, had reduced the capacity of the local furniture industry to create new designs [6]. Increasingly tough competition in overseas markets seems to be responsible for the problems affecting the local rattan furniture industry.

The only way to get out from this horrible situation is for Cirebon producers to create their own de-signs and sell them on the international market. Through this design intervention program, local de-signers should develop their own potency in the future regarding new style of rattan furniture. One of the methods is increasing the value of rattan goods as an exclusive product. This program is just the trigger to open the latency ability of in-house de-signers. To promote the development of original designs, the current situation in which original designs are illegally appropriated must be changed. However, by the fact of recent data, we still expressed optimism that Cirebon could still find certain market niches with new design by applying new method and good design principles in the international rattan furniture market.

Producers should learn how to utilize other substitute non-rattan materials that are currently not used in furniture production. During observation, many natural items have been identified which suitable to produce as a rope for wickers. One of the potentials one is dried eceng gondok, a plant on which now relies on to survive. This is one of the ways to escape from the dependencies of rattan local stock that showed decrease in supply. The rest are simply not used and seems promising due to the less of competitor and raw material price.

According to the program of intervention, we come to the conclusion which pointed as follows:

1. Rattan furniture has enormous export potential due to the volume of natural resources. Sustained supply of quality rattan is important. Regulation of export ban is needed to re-evaluate.

2. Maintaining close links to, and regular feedback from, the market is important for ensuring the sustainability of the unit in small-medium scale enterprises.

3. Producing rattan furniture is skills dependent. However it offers workers considerable opportunities for skills enhancement. A program of design skills development coupled with staff promotion will maintain the vitality of the unit and impact to the confidence level of local designer. This also confirms the approach of rural development con-ducted by [7]. 
4. Establishing a design department within the unit would be beneficial. Developing new designs can help maintain and develop market presence. Sustainability of intervention program is needed.

5. Cirebon rattan industry needs to rework its relationship with its buyers so that it does not merely manufacture the designs they dictate, but instead presents its own designs and the buyers choose which ones they want. Under this new relation-ship, the Cirebon rattan industry could escape from its current subcontractor status and surely achieve great growth and development.

\section{Acknowledgement}

This study is supported by ITB Research Grant. We gratefully acknowledge Drs. A. Gustiar, Head of Regional Office, Department of Industry and Trade, Bandung, for his technical assistance.

\section{References}

[1] Sriwarno, A.B. 2001. Strategi pengembangan desain mebel melalui pendekatan Hak atas Kekayaan Intelektual (Studi Kasus : Industri Mebel dan Kerajinan Rotan Tegalwangi, Cirebon. Institute of Technology Bandung.

[2] Yamamoto, Y. 2005. JPO Cooperation in Human Resource Development -Towards Promoting Design - Report from Cirebon, Indonesia. Technical Report in Intellectual Prop-erty of PT. Hakindah International, Indonesia.

[3] Sriwarno, A.B. 2004. Konteks Usaha Pengembangan Desain Mebel Rotan di Lingkungan Industri Rotan Cirebon dan Penerapan Sistem HKI (Hak Kekayaan Intelektual). Jurnal Desain 2d3D, 1(2), pp. 99-124.

[4] Santoso S.E. 2007. The socio-economic impact of rattan in-dustry cluster in Plumbon and Weru region, Cirebon regency, West Java, Indonesia. Thesis, Program Studi Mag-ister Perencanaan Kota dan Daerah, Jurusan Ilmu-Ilmu Teknik.

[5] Aulia, H. 2005. Tinjauan biaya pemasaran terhadap produk jadi kerajinan rotan pada CV Limindo Utama di Cirebon. Technical Report. Fakultas Bisnis dan Manajemen Jurusan Manajemen Diploma III, Widyatama University, Bandung.

[6] Pekerti, S. 2002. Product brief furniture industry. Foreign Ag-ricultural Service, GAIN Report, Global Agriculture In-formation Network Indonesia.

[7] Maxwell, J. 2002. Sulaksono, B., Budiyati S., Hastuti, Akhmadi, Munawar W., Rahayu, S.K.. Village Non-Farm Eco-nomic Activity: An Account from A Village in Kabupaten Cirebon. Technical Report of SEMERU Research Group. 